\title{
Defective In Vitro Production of $\gamma$-Interferon and Tumor Necrosis Factor- $\alpha$ by Circulating T Cells from Patients with the Hyper-Immunoglobulin E Syndrome
}

Gianfranco Del Prete, Antonio Tiri, Enrico Maggi, Marco De Carli, Donatella Macchia, Paola Parronchi, Maria E. Rossi, Maria C. Pietrogrande, Mario Ricci, and Sergio Romagnani

Clinica Medica III and Clinica Pediatrica, University of Florence, Policlinico Careggi, 50134 Florence, Italy; and Clinica Pediatrica, University of Milan, 20122 Milan, Italy

\begin{abstract}
Circulating $T$ cells from four patients with the hyper-IgE syndrome were found to produce significantly lower concentrations of interferon-gamma (IFN- $\gamma$ ) in response to stimulation with phytohemagglutinin (PHA) than did $T$ cells from eight age-matched healthy controls, three patients with atopic dermatitis and one patient with chronic granulomatous disease. A clonal analysis revealed that patients with hyper-IgE syndrome had markedly lower proportions of circulating $T$ cells able to produce IFN- $\gamma$ and tumor necrosis factor- $\alpha$ (TNF- $\alpha$ ) in comparison with controls. In contrast, the proportions of peripheral blood $T$ cells able to produce IL-4 or IL-2 were not significantly different in patients and controls. All the four patients with hyper-IgE syndrome showed high proportions of circulating $\mathrm{CD4}^{+}$helper $\mathrm{T}$ cells able to induce IgE synthesis in allogeneic B cells, as well. Such an activity for IgE synthesis appeared to be positively correlated with IL-4 production by $T$ cells and inversely related to the ability of the same $T$ cells to produce IFN- $\gamma$. Since IFN- $\gamma$ exerts an inhibitory effect on the synthesis of IgE and both IFN- $\gamma$ and TNF- $\alpha$ play an important role in inflammatory reactions, we suggest that the defective production of IFN- $\gamma$ may be responsible for hyperproduction of IgE and the combined defect of IFN- $\gamma$ and TNF- $\alpha$ may contribute to the undue susceptibility to infections seen in patients with hyper-IgE syndrome.
\end{abstract}

\section{Introduction}

Patients with the hyper-IgE (or Buckley's) syndrome have recurrent severe infections secondary to Staphylococcus aureus or to other bacteria or fungi and a history of pruritic dermatitis earlier in life (1). Laboratory findings include exceedingly high serum IgE, low grade blood eosinophilia, and specific IgE against Staphylococcus aureus. Other immune abnormalities include depressed delayed-type cutaneous hypersensitivity $(\mathrm{DTCH})^{1}$ and lymphocyte proliferation to recall antigens, altered chemotaxis of neutrophils and monocytes and deficient

Address reprint requests to Dr. Romagnani, Istituto di Clinica Medica III, Viale Morgagni, 85, I-50134 Firenze, Italy.

Received for publication 8 December 1988 and in revised form 20 July 1989.

1. Abbreviations used in this paper: DTCH, delayed type cutaneous hypersensitivity; PB, peripheral blood; SN, supernatants; TCC, T cell clones.

J. Clin. Invest.

(C) The American Society for Clinical Investigation, Inc.

$0021-9738 / 89 / 12 / 1830 / 06 \$ 2.00$

Volume 84, December 1989, 1830-1835
T cell suppressor activity (2). However, the nature of the defect(s) responsible for these abnormalities is still unclear.

IFN- $\gamma$ is a T cell-derived lymphokine that exerts a series of effects on different cell types involved in either specific or nonspecific immunity (3). Since it has recently been shown that IFN- $\gamma$ is also an important factor for regulation of the IL-4-induced IgE synthesis in both mice and humans $(4,5)$, we have examined the ability of circulating $T$ cells from four patients with hyper-IgE syndrome to produce IFN- $\gamma$, tumor necrosis factor- $\alpha$ (TNF- $\alpha$ ), IL-2 and IL-4 in response to stimulation with phytohemagglutinin (PHA). In all the four patients a great reduction of circulating $\mathrm{T}$ cells inducible to IFN- $\gamma$ and TNF- $\alpha$ production was found. We suggest that reduced IFN- $\gamma$ production primarily accounts for hyperproduction of IgE and the combined defect of IFN- $\gamma$ and TNF- $\alpha$ may contribute to deficiency of cell-mediated and nonspecific immunity observed in patients suffering from this syndrome.

\section{Methods}

Subjects. Peripheral blood (PB) T lymphocytes were obtained from four female patients, 7 (patient D.S.), 13 (patient D.A.), 18 (patient C.O.) and 21 (patient S.C.) yr old, with the hyper-IgE syndrome. Family history was negative for allergies or IgE-related disorders. From early infancy they had high serum $\mathrm{IgE}(>4,000 \mathrm{IU} / \mathrm{ml})$ and recurrent severe episodes of pneumonia secondary to Staphylococcus aureus and/or Hemophilus influenzae. Patients D.A. and S.C. developed pneumatocoeles that required thoracic surgery. All four patients had coarse facies and chronic dermatitis with recurrent staphylococcal abscesses and chronic mucocutaneous candidiasis. At the time of this study their IgE levels were 7,200 (patient D.S.), 9,900 (patient D.A.), 8,600 (patient C.O.) and 22,000 IU/ml (patient S.C.). Serum IgG values were normal in two (D.S. and D.A.) and elevated in the other two patients (SC: 1,900 and CO: $3,350 \mathrm{mg} / \mathrm{dl}$ ). Eosinophilia was consistently present in C.O., S.C., and D.S. Blood lymphocytes were within normal values, with $\mathrm{CD} 4$ to $\mathrm{CD} 8$ ratios ranging from 2.6 (D.A.) to 3.9 (S.C.). D.A. and S.C. showed defective polymorphonuclear chemotaxis, impaired phagocytosis, and reduced killing of Candida albicans. Reduced DTCH response to recall antigens was present in all patients.

PB T lymphocytes were also obtained from three female patients, 15 (T.A.), 17 (B.C.), and $20 \mathrm{yr}$ (A.R.), with untreated atopic dermatitis, food allergy, and elevated serum IgE. At the time of this study their IgE levels were 2,200 (A.R.), 3,400 (T.A.), and 4,700 (B.C.) IU/ml. A 12-yr old male patient (C.A.) with chronic granulomatous disease was also included in this study. Since 3 mo of age he suffered frequent perianal, inguinal, and peritoneal abscesses, recurrent episodes of lymphadenopathy, ulcerative stomatitis, and pneumonia due to Haemophilus and Pseudomonas. Since $10 \mathrm{yr}$ of age, when an excavative lesion of the left lung was colonized with Aspergillus fumigatus, a permanent treatment with antimycotic agents was added to continuous antibiotic therapy. Laboratory tests showed a severely reduced nitro-blue tetrazolium test, highly defective chemiluminescence and marked deficiency of superoxide radical production. At the time of this study his serum IgE 
level was $620 \mathrm{IU} / \mathrm{ml}$. Eight nonallergic female subjects (age 11-26) were selected as donors of $T$ cells on the basis of a negative history for allergies and on the basis of serum IgE level $<20 \mathrm{IU} / \mathrm{ml}$. 22 adult nonallergic subjects (laboratory personnel and students with negative history for allergies and a serum IgE level $<20 \mathrm{IU} / \mathrm{ml}$ ), selected because in previous assays their $B$ cells usually showed poor or no spontaneous IgE synthesis in vitro, were used as B cell donors.

Reagents. IL-2 and IL-4, obtained by the recombinant DNA technology, were kindly provided by Glaxo (Geneva, Switzerland) and by Unicet (Dardilly, Lyon, France), respectively. The production and characterization of anti-human $\epsilon$ chain MAb (E-45) and of rabbit antibody specific for the human $\epsilon$ chain have been detailed in a previous paper (5). Affinity-purified rabbit IgG antibody directed against human $\gamma$ chain or mouse Ig were prepared as detailed (5). The production and characterization of mouse monoclonal and of rabbit antihuman IL-4 have been reported elsewhere (5).

Preparation of $T$ cells and $T$ cell clones (TCC). Unfractionated $\mathrm{T}$ cells were prepared by E-rosetting (6). TCC were established as detailed elsewhere $(7,8)$. Briefly, purified T cells from the PB of patients and controls were seeded in limiting numbers in round-bottomed microwells $\left(0.3\right.$ cells/well) containing $10^{5}$ feeder cells and PHA ( $\left.1 \% \mathrm{vol} / \mathrm{vol}\right)$ in a final volume of $0.2 \mathrm{ml}$ medium supplemented with $10 \%$ heat-inactivated fetal calf serum (Hyclone Laboratories, Logan, UT) (complete medium). Spleen cell suspensions to be used as a source of feeder cells were irradiated with 5,000 rad. Microcultures were supplemented after $48 \mathrm{~h}$ with IL-2 $(20 \mathrm{U} / \mathrm{ml})$ and, at weekly intervals, with $10^{5}$ irradiated feeder cells and IL-2 $(20 \mathrm{U} / \mathrm{ml})$ as reported (9). After 14 to 18 $\mathrm{d}$ of culture, the number of wells containing colonies were scored, and the percentage of negative wells was calculated. The average number of cells needed to generate a single clone (precursor frequency) was determined by plotting the number of cells plated per well against the logarithm of the percentage of negative wells (10); according to one-hit Poisson statistics (10), the precursor frequency is equal to the cell density that would yield $37 \%$ negative wells. For further study, only colonies having a $90 \%$ probability of true clonality by Poisson statistics were expanded.

Preparation of supernatants of unfractionated T cells and TCC. Unfractionated PB T cells from patients and controls were cultured for $36 \mathrm{~h}$ at concentrations ranging from 1.25 to $5 \times 10^{5} / \mathrm{ml}$ of complete medium in the presence of PHA $1 \%(\mathrm{vol} / \mathrm{vol})$ and supernatants (SN) collected. Viable T blasts from a total number of 767 TCC were recovered on Ficoll-Hypaque gradient, extensively washed, resuspended at $10^{6} / \mathrm{ml}$ of complete medium in the presence of PHA $1 \%$ ( $\left.\mathrm{vol} / \mathrm{vol}\right)$. TCC were incubated at $37^{\circ} \mathrm{C}$ for $36 \mathrm{~h}$ and culture SN were collected for measurement of interleukin content.

Preparation of B cells and Ig culture system. B cell enriched suspensions, prepared as described (7), usually consisted of $45-70 \%$ B cells, $10-25 \%$ monocytes, and 5-15\% T cells. They will be referred as to B lymphocytes for simplicity. The cell culture system used for the induction of Ig synthesis was performed in duplicate tubes containing 4 $\times 10^{5} \mathrm{~B}$ cells and $4 \times 10^{5}$ clonal T blasts in $1 \mathrm{ml}$. Before using, PHApulsed $T$ blasts were washed twice and co-cultured for $10 \mathrm{~d}$ with $B$ cells in the absence of any other stimulant. After $10 \mathrm{~d}$, cultured supernatants were collected and assayed for their IgE and IgG content.

Measurement of $I g E$ and $I g G$. The radioimmunoassay for the measurement of $\operatorname{IgE}$ has been described in detail elsewhere $(7,8)$. The lower limit of sensitivity of the test was $0.3 \mathrm{ng} / \mathrm{ml}$. Spontaneous IgE synthesis was calculated by subtracting the values of preformed IgE obtained in parallel cultures containing cycloheximide $(100 \mu \mathrm{g} / \mathrm{ml})$ or treated with $1 \mathrm{~N} \mathrm{HCl}$ from IgE values found in supernatants of untreated cultures of B cells alone. The IgE synthesis in vitro induced by TCC was calculated by subtracting values of both preformed and spontaneously synthesized IgE (when detectable). The RIA used for detecting IgG in culture supernatants has also been described (6). Values of TCC-induced IgG higher than $1 \mu \mathrm{g} / \mathrm{ml}$ and of TCC-induced IgE synthesis higher than 0.5 $\mathrm{ng} / \mathrm{ml}$ above background levels (preformed plus spontaneous) were considered as positive.
Quantification of IFN- $\gamma, T N F-\alpha, I L-2$, and IL-4. For the quantitative measurement of IFN- $\gamma$ in SN of unfractionated T cells and TCC SN, two specific radioimmunoassays (Centocor, Inc., Malvern, PA, and IRE-Medgenix, Bruxelles, Belgium) were used according to the manufacturers' instructions. The coefficient of correlation between the two assays was high $(r=0.94)$ for values ranging from 2 to $100 \mathrm{U} / \mathrm{ml})$. TNF- $\alpha$ production in TCC SN was measured by a specific radioimmunoassay (IRE-Medegenix), according to the manufacturer's instruction. IL-2 was also measured with a specific RIA (IRE-Medgenix). The quantitative determination of human IL-4 was performed by a two-site sandwich ELISA (11), using a rabbit polyclonal anti-human IL-4 antibody and a rat anti-human IL-4 kindly provided by Unicet. The theoretical sensitivity of the assay was found to be $\sim 15 \mathrm{pg} / \mathrm{ml}$, whereas the useful assay range was between 40 and $1,000 \mathrm{pg} / \mathrm{ml}$. The specificity of such an ELISA was demonstrated by negative reactions with human IL-1, IL-2, IL-3, IFN- $\gamma$, GM-CSF, G-CSF, IL-6, TNF- $\alpha$, and TNF- $\beta$ (11). In our hands, the mean intraassay coefficient of variation was $11 \%$.

TCC SN showing IFN- $\gamma$, TNF- $\alpha$, IL-2, or IL-4 levels 5 SD over those of control SN derived from irradiated feeder cells alone were regarded as positive. The mean values $( \pm S D)$ of interleukin production by PHA-stimulated irradiated feeder cells alone were $2.1 \pm 1.6 \mathrm{IU} / \mathrm{ml}$ IFN- $\gamma, 180 \pm 70 \mathrm{pg} / \mathrm{ml} \mathrm{TNF-} \alpha, 0.2 \pm 0.1 \mathrm{U} / \mathrm{ml} \mathrm{IL-}$, and $45 \pm 31 \mathrm{pg} / \mathrm{ml}$ IL-4. These background values were subtracted from values obtained in each culture of PHA-stimulated TCC.

Statistical analysis. Statistical analysis of the results was performed by using either the $\chi^{2}$ test or Student's $t$ test.

\section{Results}

Reduced production of IFN- $\gamma$ by unfractionated $T$ cells from patients with Hyper-IgE syndrome. Graded numbers of freshly isolated $\mathrm{T}$ cells from the PB of four patients with Hyper-IgE syndrome were stimulated with PHA in order to evaluate their ability to produce IFN- $\gamma$, IL-4, and IL-2. The same procedure was applied to equal numbers of PB T cells obtained from eight healthy controls, as well as from three patients with atopic dermatitis, and one patient with chronic granulomatous disease. In at least three out of the four hyper-IgE patients the response curves of PHA-induced IFN- $\gamma$ production were markedly lower than the mean $( \pm \mathrm{SD})$ range of IFN- $\gamma$ production displayed by normal $T$ cells at equivalent cell concentrations (Table I). In the fourth patient (C.O.) the reduction of the response to PHA in terms of IFN- $\gamma$ was less marked, particularly at the highest number of $\mathrm{T}$ cells tested $\left(0.5 \times 10^{6} / \mathrm{ml}\right)$. PHA-induced IFN- $\gamma$ production by $\mathrm{T}$ cells of the patient with chronic granulomatous disease was normal, while it was only slightly decreased in patients with atopic dermatitis. Under the same experimental conditions, the amounts of IL-4 (Table I) or IL-2 (data not shown) detected in culture SN of paired numbers of PHA-stimulated $T$ cells were substantially identical both in all the types of patients and in healthy controls.

Defective production of IFN- $\gamma$ in patients with hyper-IgE syndrome is due to a marked reduction of IFN- $\gamma$ producing $T$ cells. Since functional assays on heterogeneous cell populations do not provide information on the proportion of cells expressing a given function, a clonal analysis of PB T cells from the patients with hyper-IgE syndrome included in this study was performed. To ensure that the TCC examined were representative of the general population of circulating $T$ cells in patients and controls, cloning experiments were performed by using a previously described high efficiency technique (7-9). A total of 173 TCC from hyper-IgE patients were ana- 
Table I. PHA-induced Production of IFN- $\gamma$ and $I L-4$ by Unfractionated $T$ Cells Obtained from the PB of Patients with Hyper-IgE Syndrome, Patients with Atopic Dermatitis or Chronic Granulomatous Disease and Healthy Subjects

\begin{tabular}{|c|c|c|c|c|c|c|}
\hline \multirow[b]{2}{*}{ Subjects (No. of cases) } & \multicolumn{3}{|c|}{$\begin{array}{l}\text { IFN- } \gamma \text { production }(\mathrm{U} / \mathrm{ml}) \\
\text { by graded numbers of } \mathrm{T} \\
\text { cells }\left(\times 10^{-3}\right)^{*}\end{array}$} & \multicolumn{3}{|c|}{$\begin{array}{l}\text { IL-4 production }(\mathrm{pg} / \mathrm{ml}) \text { by } \\
\text { graded numbers of } \mathrm{T} \text { cells } \\
\left(\times 10^{-3}\right)^{*}\end{array}$} \\
\hline & 125 & 250 & 500 & 125 & 250 & 500 \\
\hline
\end{tabular}

$\begin{array}{lrrrrrr}\begin{array}{l}\text { Hyper-IgE } \\ \quad \text { syndrome: }\end{array} & & & & & & \\ \text { SC } & 2 & 3 & 9 & 74 & 105 & 162 \\ \text { DA } & 4 & 7 & 19 & 49 & 114 & 184 \\ \text { DS } & 6 & 11 & 27 & 58 & 97 & 176 \\ \text { CO } & 9 & 15 & 56 & 63 & 138 & 208 \\ \text { Healthy (8) } & 14 \pm 4^{\ddagger} & 37 \pm 12 & 77 \pm 16 & 64 \pm 15 & 98 \pm 25 & 158 \pm 34 \\ \text { Atopic dermatitis: } & & & & & & \\ \text { BC } & 6 & 19 & 39 & 97 & 141 & 224 \\ \text { AR } & 10 & 24 & 52 & 53 & 116 & 168 \\ \text { TA } & 9 & 27 & 44 & 71 & 101 & 189 \\ \text { Chronic } & & & & & & \\ \quad \text { granulomatous } & & & & & & \\ \quad \text { disease (1) } & 18 & 41 & 63 & 62 & 122 & 151\end{array}$

* Freshly isolated PB T cells (at concentrations ranging from 125 to $\left.500 \times 10^{3} / \mathrm{ml}\right)$ were stimulated for $36 \mathrm{~h}$ with PHA $(1 \% \mathrm{vol} / \mathrm{vol})$ and interleukins were measured in culture supernatants.

${ }^{\ddagger}$ Results represent mean \pm SD.

lyzed and compared with 422 TCC obtained from eight agematched healthy controls as well as with 162 TCC obtained from three patients with atopic dermatitis. In 15 consecutive cloning experiments, the cloning efficiency was sufficiently high, ranging from 42 to $79 \%$ (mean $64 \%$ ). In all cases, the ratio between $\mathrm{CD}^{+}$and $\mathrm{CD}^{+}$clones substantially reflected the CD4 to CD8 ratio found in freshly isolated $T$ cell suspensions (data not shown), indicating that no substantial selection in favor of one or another subset had occurred during the cloning procedure. $T$ blasts of all clones were pulsed with PHA and culture SN were assayed for their interleukin content. As shown in Table II, in all patients, either with hyper-IgE syn- drome or with atopic dermatitis, the proportion of both $\mathrm{CD} 4^{+}$ and $\mathrm{CD}^{+}$clones showing the ability to produce IL-2 was not significantly different from that of both $\mathrm{CD}^{+}$and $\mathrm{CD}^{+}$ clones derived from healthy controls. Likewise, in patients with hyper-IgE syndrome, the proportion of $\mathrm{CD}^{+}{ }^{+} \mathrm{TCC}$ triggered to IL-4 production by PHA was not significantly different from that found in $\mathrm{CD}^{+}{ }^{+} \mathrm{TCC}$ established from either patients with atopic dermatitis or healthy controls. In contrast, the proportions of $\mathrm{CD}^{+}$(range $5-21 \%$ ) and $\mathrm{CD}^{+}$(range $12-20 \%$ ) clones derived from hyper-IgE patients showing the ability to produce IFN- $\gamma$ and TNF- $\alpha$ upon PHA stimulation, were significantly lower than that of IFN- $\gamma$-producing $\mathrm{CD}^{+}$ or $\mathrm{CD}^{+}$clones derived from control subjects. In patients with atopic dermatitis the proportion of $\mathrm{CD}^{+}$(but not of $\mathrm{CD}^{+}$) TCC able to produce IFN- $\gamma$ was lower than that of controls, but it was largely higher than that found in patients with hyper-IgE syndrome.

Patients with hyper-IgE syndrome possess increased proportions of $\mathrm{CD}^{+}$clones able to provide helper function for IgE synthesis. All the $142 \mathrm{CD}^{+} \mathrm{TCC}$ from hyper-IgE patients were compared with control $166 \mathrm{CD} 4^{+} \mathrm{TCC}$ (from four randomly selected controls) and with $84 \mathrm{CD}^{+}{ }^{+} \mathrm{TCC}$ from two patients (B.C. and A.R.) with atopic dermatitis for their ability to induce IgE and IgG synthesis in allogeneic B cells of different donors. To this end, $T$ blasts from each clone were preactivated for $24 \mathrm{~h}$ with PHA, washed and co-cultured for additional $10 \mathrm{~d}$ (at a 1:1 ratio), with $0.4 \times 10^{6}$ normal $B$ cells without any other stimulant. It was found that helper activity for IgE synthesis was a property shared by a high proportion of $\mathrm{CD}^{+}$clones from all the hyper-IgE patients ( $52 \%$ in D.S., $49 \%$ in D.A., $42 \%$ in C.O., and $57 \%$ in S.C.), whereas only $9,12,15$, and $24 \%$ of $\mathrm{CD}^{+}$clones from healthy controls or 25 (A.R.) and $29 \%$ (B.C.) of $\mathrm{CD}^{+}$TCC from patients with atopic dermatitis displayed helper function for IgE in allogeneic B cells. In contrast, the proportions of $\mathrm{CD}^{+}$clones with helper function for IgG were not significantly different between patients with hyper-IgE syndrome, patients with atopic dermatitis and controls $(51-71 \%$ vs. $57-64 \%$ vs. $55-66 \%$, respectively).

When values of IFN- $\gamma$ produced by single $\mathrm{CD4}^{+}$clones were plotted against the mean values of IgE induced by the same clones in cultures of responder B cells, an inverse correlation was found between the rate of IFN- $\gamma$ production and the degree of helper function for IgE. Such an inverse relationship

Table II. PHA-induced Production of IFN- $\gamma, T N F-\alpha, I L-2$, and IL-4 by T Cell Clones Derived from the PB of Patients with Hyper-IgE Syndrome, Patients with Atopic Dermatitis, and Normal Individuals

\begin{tabular}{|c|c|c|c|c|c|c|}
\hline \multirow[b]{2}{*}{ Subjects (No. of cases) } & \multirow[b]{2}{*}{ T cell clone phenotype } & \multirow[b]{2}{*}{ No. of clones tested } & \multicolumn{4}{|c|}{ No. of clones producing } \\
\hline & & & IFN- $\gamma$ & TNF- $\alpha$ & IL-2 & IL-4 \\
\hline \multirow[t]{2}{*}{ Healthy (8) } & $\mathrm{CD}^{+}$ & 294 & $159(54 \%)^{*}$ & $141(48 \%)^{* *}$ & $157(53 \%)$ & $118(40 \%)$ \\
\hline & $\mathrm{CD}^{+}$ & 128 & $71(55 \%)^{\ddagger}$ & $54(43 \%)^{\ddagger \ddagger}$ & $76(59 \%)$ & $3(2 \%)$ \\
\hline \multirow{2}{*}{ Hyper-IgE syndrome (4) } & $\mathrm{CD}^{+}$ & 142 & $15(11 \%)^{\S}$ & $19(15 \%)^{\S \S}$ & $91(64 \%)$ & $68(48 \%)$ \\
\hline & $\mathrm{CD}^{+}$ & 41 & $6(15 \%)^{\prime \prime}$ & $5(12 \%)^{\mathrm{sT}}$ & $25(61 \%)$ & $2(5 \%)$ \\
\hline \multirow[t]{2}{*}{ Atopic dermatitis ( 3 ) } & $\mathrm{CD} 4$ & 123 & $52(42 \%)^{\pi}$ & ND & $66(54 \%)$ & $61(49 \%)$ \\
\hline & $\mathrm{CD}^{+}$ & 39 & $23(59 \%)$ & ND & $23(59 \%)$ & ND \\
\hline
\end{tabular}

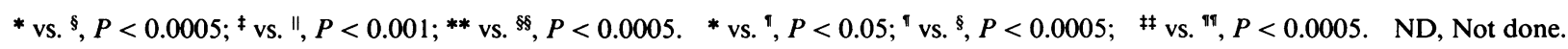


was statistically significant $(P<0.005)$ in control clones from healthy subjects or patients with atopic dermatitis, and even more significant $(P<0.001)$ in clones derived from hyper-IgE patients, where only 1 of the $70 \mathrm{CD}^{+}$clones able to provide help for IgE was able to produce detectable amounts of IFN- $\gamma$, as well (Fig. 1). When the amounts of IgE induced in B cells by $\mathrm{CD} 4^{+}$clones were plotted against the ratios between the levels of their IL-4 and IFN- $\gamma$ production, a highly significant correlation $(P<0.001)$ was found in both patients and healthy or disease controls ( $r=0.88,0.87$, and 0.84 , respectively), suggesting that a balance largely in favor of IL-4 production was essential for TCC to provide help for IgE. Since most of IL-4producing clones from healthy subjects showed concomitant production of substantial amounts of INF- $\gamma$, the number of clones with high IL-4 to IFN- $\gamma$ ratios was limited to 26 of 69 IL-4-producing clones. In patients with atopic dermatitis, the proportion of clones with high IL-4 to IFN- $\gamma$ ratios was also

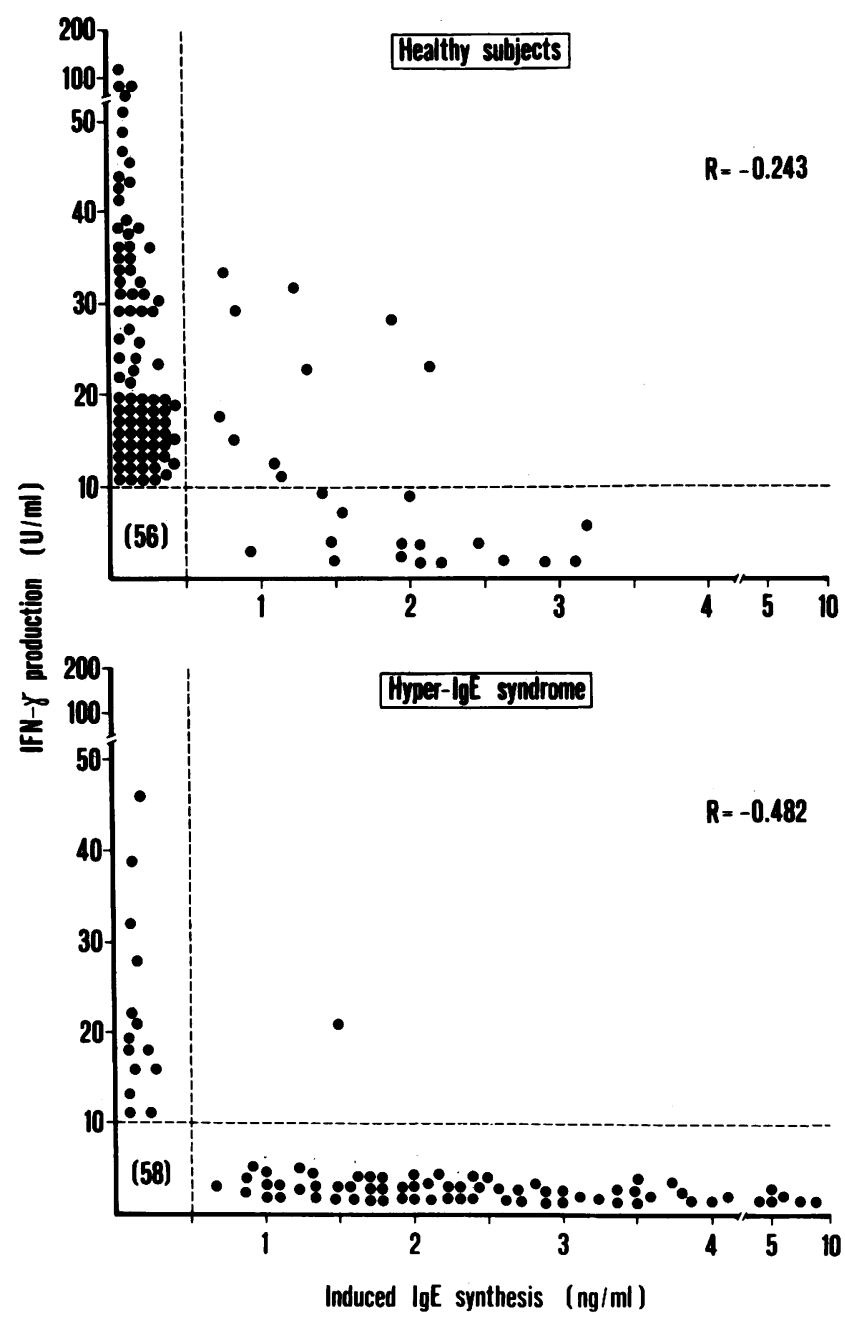

Figure 1 . Inverse relationship between IFN- $\gamma$ production and helper activity for in vitro IgE synthesis exerted by TCC from patients with hyper-IgE and healthy controls. Dotted lines represent 5 SD values above the mean spontaneous IgE synthesis (calculated as reported in Methods) or the mean content in IFN- $\gamma(2.1 \pm 1.6 \mathrm{U} / \mathrm{ml})$ of SN from irradiated feeder cells alone. Values in parentheses indicate the number of TCC showing neither help for IgE, nor IFN- $\gamma$ production. limited to 23 of 42 IL-4-producing clones. In contrast, in hyper-IgE patients, the proportion of $\mathrm{CD} 4^{+}$clones with IL- 4 to IFN $-\gamma$ ratios in favor of the former (due to defective IFN- $\gamma$ production) was much higher and included $100 \%$ of IL-4-producing clones.

\section{Discussion}

Hyper-IgE syndrome is characterized by abnormally high serum IgE levels and defects of both cell-mediated immunity and leukocyte function, which associates with enhanced susceptibility to bacterial and fungal infections (2). Enhanced IgE production has also been observed in patients with primary immune deficiencies of the $T$ cell system (12). To explain these findings, it has been suggested that these patients have a numerical and/or functional defect of suppressor $T$ cells $(2,13)$. A sharp increase in serum IgE has indeed been demonstrated in bone marrow-transplanted patients during the acute phase of the graft versus host reaction, which is characterized by a reduction of suppressor $T$ cells (14). Finally, the most common condition associated with enhanced IgE production is atopy. However, the nature of immune alterations responsible for the hyperproduction of IgE in atopic patients as well as in other pathological conditions still remains unclear. Mechanisms that regulate $\mathrm{IgE}$ synthesis have not yet been fully elucidated.

Recent experiments conducted in rodents have shown that IL-4 (ex-BSF-1), a product of Th2 helper cells, is able to induce the synthesis of high amounts of IgE on lipopolysaccharidestimulated mouse splenic B cells, whereas IFN- $\gamma$, which is released by Thl helper cells, exerts inhibitory effect on the IL-4-mediated IgE synthesis $(4,15)$. More recently, we were able to demonstrate that IL- 4 and IFN- $\gamma$ play a reciprocal regulatory role on human IgE synthesis as well (5). Thus, excessive production of IL-4, defective production of IFN- $\gamma$, or both may be responsible for hyperproduction of $\mathrm{IgE}$.

In this report, we have shown that circulating $\mathrm{T}$ cells from four patients with hyper-IgE syndrome produced significantly lower concentrations of IFN- $\gamma$ in response to PHA than did T cells from age-matched healthy controls. To investigate whether such a defective production of IFN- $\gamma$ was a nonspecific response to high circulating levels of IgE or to recurrent infections, three patients with atopic dermatitis and one patient with chronic granulomatous disease were analyzed for the ability of their PB T cells to produce IFN- $\gamma$ upon stimulation with PHA. It was found that, except for an atopic patient (B.C.), none of the other patients selected as disease controls showed a significant reduction in IFN- $\gamma$ production. These data make it unlikely that defective production of IFN- $\gamma$ is merely the consequence of elevated serum IgE levels or of recurrent infections. The analysis of this phenomenon at the clonal level revealed that the marked defect of IFN- $\gamma$ production in hyper-IgE patients reflected a strong decrease in the number of circulating $\mathrm{CD}^{+} \mathrm{T}$ cells potentially inducible to IFN- $\gamma$ production. In addition, a significant reduction of IFN- $\gamma$-producing cells was also found in the $\mathrm{CD}^{+} \mathrm{T}$ cell subset. Thus, even though our hyper-IgE patients failed to show remarkable numerical defects of $\mathrm{CD}^{+}$suppressor/cytotoxic cells, as observed by others $(2,14)$, they certainly had a significant reduction in the number of cells exerting IFN- $\gamma$-mediated suppressor function on IgE synthesis. In comparison with 
healthy controls, a moderate reduction of circulating $\mathrm{CD}^{+} \mathrm{T}$ cells able to produce IFN- $\gamma$ was also found in patients with atopic dermatitis and elevated serum IgE. However, the proportion of such $\mathrm{CD}^{+}$cells was much higher than that found in the PB of hyper-IgE patients and the proportion of IFN- $\gamma$ producing $\mathrm{CD}^{+} \mathrm{T}$ cells was completely normal.

All patients with hyper-IgE syndrome showed proportions of helper $\mathrm{T}$ cells able to induce IgE synthesis in vitro signifcantly higher than those found in either atopic patients or healthy controls. However, such an increased helper activity for IgE was not apparently due to an increase of IL-4-producing $T$ cells or to abnormally high secretion rate of IL-4, but it was rather related to reduced proportions of $\mathrm{T}$ cells able to produce IFN- $\gamma$. It has recently been shown that a clear-cut dichotomy between IL-4- and IFN- $\gamma$-producing Th cells, as found in mice (4), does not exist in humans $(16,17)$. These findings have been confirmed in the present study because the majority of IL-4-producing TCC from both healthy subjects and patients with atopic dermatitis showed concomitant production of IFN- $\gamma$. In contrast, in hyper-IgE patients the proportion of IL-4-producing TCC was substantially similar to that observed in either healthy or disease controls, but the great majority of these TCC failed to produce IFN- $\gamma$. Thus, there is reasonable evidence to hypothesize that the enhanced in vivo IgE production in patients with hyper-IgE syndrome is related, at least in part, to a defective potential of IFN- $\gamma$ secretion.

Besides its regulatory activity on IgE synthesis, IFN- $\gamma$ has been shown to exert a series of pleiomorphic effects on immune cells, myelomonocytic cells and other cell types (3). For example, IFN- $\gamma$ enhances the cytotoxic activity of NK cells (18) and induces the expression of class II MHC antigens on macrophages, thus enhancing their ability to function as antigen-presenting cells (19). IFN- $\gamma$ also acts on the effector cells of nonadaptive resistance, regulating proliferation, differentiation and activity of neutrophilic granulocytes and monocytes $(20,21)$. In this study, we found that patients with the hyperIgE syndrome had reduced proportions not only of IFN- $\gamma$ producing $\mathrm{T}$ cells, but also of T cells able to release TNF- $\alpha$, which plays an important role in immune inflammatory reactions, as well (22). Taken together, these findings may explain why patients with hyper-IgE syndrome, in addition to the production of exceedingly high amounts of $\mathrm{IgE}$, display a series of abnormalities of both $\mathrm{T}$ cell-mediated and nonspecific immunity that result in reduced defence against some infectious agents.

The possible therapeutic implications of these in vitro data are obviously still uncertain. Recently, however, it has been shown that two patients with AIDS, who had exacerbations of previously quiescent atopic diseases, showed a striking improvement of symptoms and cellular abnormalities after treatment with recombinant IFN- $\gamma(23)$. Thus, it is not unreasonable to suggest that treatment with IFN- $\gamma$ may represent a new interesting therapeutical approach also in patients with the hyper-IgE syndrome.

\section{Acknowledgments}

This work was supported by grants from Consiglio Nazionale delle Ricerche (87.01508 and 88.00850) and from Associazione Italiana per la Ricerca sul Cancro.

\section{References}

1. Buckley, R. H., B. B. Wray, and E. Z. Belmaker. 1972. Extreme hyperimmunoglobulinemia $\mathrm{E}$ and undue susceptibility to infection. Pediatrics. 49:59-70.

2. Buckley, R. H., and W. G. Becker. 1978. Abnormalities in the regulation of human IgE synthesis. Immunol. Rev. 41:288-314.

3. Trinchieri, G., and B. Perussia. 1985. Immune interferon: a pleiotropic lymphokine with multiple effects. Immunol. Today. 6:131-136.

4. Coffman, R. L., and J. Carty. 1986. A T cell activity that enhances polyclonal IgE production and its inhibition by interferon- $\gamma . J$. Immunol. 136:949-954.

5. Del Prete, G. F., E. Maggi, P. Parronchi, I. Chretien, A. Tiri, D. Macchia, M. Ricci, J. Banchereau, J. de Vries, and S. Romagnani. 1988. IL-4 is an essential factor for the IgE synthesis induced in vitro by human T cell clones and their supernatants. J. Immunol. 140:41934198.

6. Romagnani, S., G. F. Del Prete, E. Maggi, G. Bellesi, G. Biti, P. L. Rossi Ferrini, and M. Ricci. 1983. Abnormalities of in vitro immunoglobulin synthesis by peripheral blood lymphocytes from untreated patients with Hodgkin's disease. J. Clin. Invest. 71:1375-1382.

7. Del Prete, G. F., E. Maggi, D. Macchia, A. Tiri, P. Parronchi, M. Ricci, and S. Romagnani. 1986. Human T cell clones can induce in vitro IgE synthesis in normal B cells regardless of alloantigen recognition or specificity for peculiar antigens. Eur. J. Immunol. 16:15091514.

8. Romagnani, S., G. F. Del Prete, E. Maggi, and M. Ricci. 1987. Activation through CD3 molecule leads a number of human $T$ cell clones to induce IgE synthesis in vitro by B cells from allergic and nonallergic individuals. J. Immunol. 138:1744-1749.

9. Moretta, A., G. Pantaleo, L. Moretta, J. C. Cerottini, and M. C. Mingari. 1983. Direct demonstration of the clonogenic potential of every human peripheral blood T cells. Clonal analysis of HLA-DR expression and cytolytic activity. J. Exp. Med. 157:743-751.

10. Taswell, C. 1981. Limiting dilution assays for the determination of immunocompetent cell frequencies. J. Immunol. 126:16141619.

11. Chretien, I., A. Van Kimmenade, M. K. Pearce, J. Banchereau, and J. S. Abrams. 1989. Development of polyclonal and monoclonal antibodies for immunoassay and neutralization of human IL-4. $J$. Immunol. Methods. 117:67-81.

12. Buckley, R. H., and S. A. Fiscus. 1975. Serum IgD and IgE concentrations in immunodeficiency diseases. J. Clin. Invest. 55:157165.

13. Geha, R. S., E. Reinherz, D. Leung, K. T. McKee, S. Schlossman, and F. S. Rosen. 1981. Deficiency of suppressor T cells in hyperimmunoglobulin E syndrome. J. Clin. Invest. 68:783-790.

14. Ringden, O., U. Persson, S. G. O. Johansson, H. Wilczek, G. Gahrton, C. G. Groth, G. Lundgren, B. Lonqvist, and E. Moller. 1983. Markedly elevated serum IgE levels following allogeneic and syngeneic bone marrow transplantation. Blood. 61:1190-1195.

15. Snapper, C. M., and W. E. Paul. 1987. Interferon- and B cell stimulatory factor-1 reciprocally regulate $\mathrm{Ig}$ isotype production. Science (Wash. DC). 236:944-949.

16. Maggi, E., G. F. Del Prete, D. Macchia, P. Parronchi, A. Tiri, I. Chretien, M. Ricci, and S. Romagnani. 1988. Profiles of lymphokine activities and helper function for IgE in human T cell clones. Eur. $J$. Immunol. 18:1045-1050.

17. Paliard, X., R. De Waal Malefijt, H. Yssel, D. Blanchard, I. Chretien, J. Abrams, J. De Vries, and H. Spits. 1988. Simultaneous production of IL-2, IL-4, and IFN- $\gamma$ by activated human $\mathrm{CD}^{+}$and $\mathrm{CD}^{+} \mathrm{T}$ cell clones. J. Immunol. 141:849-855. 
18. Djeu, J. Y., N. Stocks, K. Zoon, G. J. Stanton, T. Timonen, and R. B. Herberman. 1982. Positive self-regulation of cytotoxicity in human natural killer cells by production of interferon upon exposure to influenza and herpes virus. J. Exp. Med. 156:1222-1233.

19. Steeg, P. S., R. N. Moore, H. M. Johnson, and J. S. Oppenheim. 1982. Regulation of murine macrophage Ia antigen expression by a lymphokine with immune interferon activity. J. Exp. Med. 156:17801793.

20. Perussia, B., E. T. Dayton, V. Fanning, P. Thiagarajan, J. Hoxie, and G. Trinchieri. 1983. Immune interferon and leukocyte conditioned medium induce normal and leukemic myeloid cells to differentiate along the monocytic pathway. J. Exp. Med. 158:20582080.
21. Nathan, C. F., H. W. Murrary, M. E. Wiebe, and B. Y. Rubin. 1983. Identification of interferon- $\gamma$ as the lymphokine that activates human macrophage oxidative metabolism and antimicrobial activity. J. Exp. Med. 158:670-689.

22. Pennica, D., G. E. Nedwin, J. S. Hayflick, P. H. Seeburg, R. Derynck, M. A. Palladino, W. J. Kohr, B. B. Aggarwal, and D. V. Goeddel. 1984. Human tumor necrosis factor: precursor structure, expression and homology to lymphotoxin. Nature (Lond.). 312:724729.

23. Parkin, J. M., L. J. Eales, A. R. Galazka, and A. J. Pinching. 1987. Atopic manifestations in the acquired immune deficiency syndrome: response to recombinant interferon gamma. $\mathrm{Br}$. Med. J. 294:1185-1186. 